\title{
Who is having a voice? Journalists' selection of sources in a creationism controversy in the UK press
}

\author{
Joachim Allgaier
}

Received: 17 May 2010/ Accepted: 7 February 2011/Published online: 17 March 2011

(C) The Author(s) 2011. This article is published with open access at Springerlink.com

\begin{abstract}
Media accounts of reality have the potential to influence public opinion and decision making processes. Therefore who has and who does not have access to the media and can make their voice heard is a crucial question with serious political consequences. In this article it is investigated whether the speciality of journalists influences their source selection procedures. The coverage of science in schools is an interesting example, since it can be covered by specialized science or education correspondents, but also by general news reporters. A public controversy in the UK about the inclusion of creationism in a school is used to identify which types of sources were selected by various journalists. The focus is upon the selection of sources and whether journalists with different specialties consider various sources relevant and credible. A content analysis of articles, featuring this controversy, is combined with an analysis of correspondent's strategies for selecting sources based on interviews with them. The findings suggest that compared to journalists that specialize in education issues, science correspondents employ a narrower scope when seeking sources. This might have important consequences for the representation of views on science education in the media.
\end{abstract}

Keywords Journalistic practice $\cdot$ Sources $\cdot$ Specialist correspondents $\cdot$ Education coverage $\cdot$ Objectivity

\section{Kurzfassung}

In den Sozialwissenschaften wird davon ausgegangen, dass bei Fragestellungen hinsichtlich Bildung, Wissenschaft und Technik, die die öffentliche Meinung und auch politische Entscheidungsfindungsprozesse betreffen, den Medien eine zentrale Vermittlerrolle zukommt. Dies gilt insbesondere für die Auswahl und Legitimierung von

\footnotetext{
J. Allgaier ( ()

Institute of Neuroscience and Medicine, Ethics in the Neurosciences (INM-8),

Research Center Juelich, 52425 Juelich, Germany

e-mail: jo.allgaier@fz-juelich.de
} 
wissenschaftlichen und anderen Quellen, sowie für Fragen der Glaubwürdigkeit, Relevanz und Autorität in der Repräsentation dieser Quellen in den Medien.

In dieser Fallstudie werden anhand eines öffentlichen Streits um Evolutionstheorie und Schöpfungsmythos im naturwissenschaftlichen Unterricht an einer mehrfach ausgezeichneten Schule in England (Emmanuel College in Gateshead) die Auswirkungen unterschiedlicher Spezialisierungen von Journalisten auf die Auswahl von Quellen in der Berichterstattung untersucht. Die Auswahl dieser Kontroverse diente hierbei dazu, mehr über die Medienberichterstattung und Quellenauswahl zum Thema Wissenschaft an Schulen herauszufinden.

Die Darstellung basiert auf der Analyse der in Zeitungsartikeln zitierten Quellen über diese Kontroverse, sowie auf qualitativen Interviews mit unterschiedlichen Journalisten, die über diese Debatte in der britischen Presse berichteten. Die Analyse von 111 Zeitungsartikeln in der britischen Presse führt zu dem Ergebnis, dass die unterschiedlichen journalistischen Spezialisierungen einen sichtbaren Einfluss auf die Auswahl der in den Artikeln zitierten Quellen haben. So sind beispielsweise über die Hälfte der Quellen, die von Wissenschaftsjournalisten in ihren Artikeln zitiert werden, Wissenschaftler. Journalisten, die auf Bildungsthemen spezialisiert sind, zitieren hingegen, ebenso wie allgemeine Zeitungsreporter, ein wesentlich breiteres Spektrum an Quellen.

Dies wurde in den Interviews mit unterschiedlich spezialisierten Journalisten bestätigt. Ein spezialisierter Wissenschaftsjournalist sah auch hier naturwissenschaftliche Experten als die relevantesten Quellen an. In der Auswahl der Quellen spielte jedoch auch die Reputation der Experten, sowie die persönliche Bekanntschaft und bisherige vertrauensvolle Zusammenarbeit eine Rolle. Journalisten, die auf die Berichterstattung von Bildungsthemen spezialisiert sind, nannten hingegen andere für sie relevante Quellen: Dies waren etwa der Rektor und die Lehrer (und Schüler) des Emmanuel Colleges, Vertreter der Lehrergewerkschaften, relevante Behörden und Regierungsvertreter, aber keine wissenschaftliche Experten. Die Korrespondentin einer Lokalzeitung meinte, dass es außerdem die Aufgabe von regionalen Medien sei, die Stimmen von Bürgerinnen und Bürgern der lokalen Gemeinde zu repräsentieren. Die Analyse der Zeitungsartikel zur Quellenauswahl bestätigte diese Aussagen.

In den Erzählungen von Journalisten spielte zudem die Ausgewogenheit der Berichterstattung eine wichtige Rolle. In der Praxis bedeutet dies, dass bei einer in ihren Augen objektiven Berichterstattung die Stimmen der einen Seite mit den Stimmen der anderen Seite kontrastiert werden müssen. Unter den befragten Journalisten weigerte sich jedoch ein Wissenschaftsjournalist, diesen Fall als legitime Kontroverse zu betrachten. Für ihn waren die Stimmen von Evolutionsgegnern irrelevant und er sah es als seine Aufgabe an, vor allem die Meinung der wissenschaftlichen Experten gegen Kreationismus zu vertreten. Diese in den Naturwissenschaften vorherrschende Objektivitätsvorstellung ist inkompatibel mit den allgemeinen Objektivitätsvorstellungen der journalistischen Praxis. In der Stichprobe der befragten Journalisten handelt es bei dieser Herangehensweise um einen Einzelfall.

Die Auswahl der Expertenquellen wird jedoch auch von praxisrelevanteren Kriterien des journalistischen Arbeitsalltags beeinflusst. Journalisten müssen beispielsweise oft sehr schnell auf eingehende Nachrichten reagieren. Deshalb spielt in der Praxis die rasche Kontaktmöglichkeit und schnelle Verfügbarkeit der Quellen eine wichtige Rolle.

Die Ergebnisse werfen die Frage auf, zu welchen Repräsentationen von Wissenschaft an Schulen die Berichterstattung durch unterschiedliche Korrespondenten führt, und auch welche Zwecke und Ziele des naturwissenschaftlichen Unterrichts durch die Auswahl unterschiedlicher Quellen in der Öffentlichkeit betont werden. 


\section{Purpose and scope of the study}

It is likely that the coverage of the mass media on various topics can have an influence on how these issues are perceived and affect the opinion of the members of the public as well as the opinion of decision makers and other influential actors. Science education in schools is a topic that often falls in the area of educational and science correspondents. However, general and other news reporters can also cover stories about science education. Here it is assumed that values and practices of journalists may vary according to specialty (e.g., Turnstall 1971). It is probable that various specialist correspondents rely on different kinds of sources that are specific to their own speciality area. The research question guiding this study therefore asks whether the specialty of journalists that reported a particular story influenced their source selection processes. To answer this question newspaper articles from the UK press about a school in Britain (Emmanuel College) that was accused of teaching creationist theories in science classes were used. A range of correspondents covered this story and the focus primarily is on the sources that were selected to reference in the many news reports printed during the controversy. In this sense the purpose is to find out more about how sources come to be represented in a newspaper story that is (also) about science education. A content analysis was conducted that investigated what types of sources were quoted in this story and which role the 'specialty' of the reporting correspondents played. Additionally, different types of journalists, that reported the story, were interviewed about their source selection strategies to determine whether there are different understandings about the relevance of particular sources in this story. Although the sample is limited, the interviews with media professionals provide some illuminating insights about the journalistic practice of various reporters that for the most part has been neglected in the literature.

\section{Science education in the media}

It is common in developed, and even most developing, countries that children grow up with some form of science education. In Britain, for instance, science courses at the primary and secondary level are compulsory and it is theorized that the way this broad subject is encountered by students in their early education years has long ranging impacts on how science is perceived later in life. Early science education may also have an effect on career choices or non-choices in the science and technology sector. This suggests that science education is a vital activity, which influences how citizens view science throughout their life path. It is for this strategic reason for example that creationists have chosen science education in schools as a battleground where the boundaries between science and belief are to be redefined (McCune 2003). The problem is that scholarly works that address the interplay between society, media and science education are very rare.

For most adults without children in primary or secondary school or who are not themselves educators, the topic of science education is not a major concern in their everyday lives. If they hear or read about it, it is most likely through mass media accounts. Similar to science coverage, education coverage is a rather marginal issue in the mainstream mass media, and it is an issue that in the UK is mainly covered by specialist correspondents (Hansen 2007). Although the media profile of education related news stories in the UK has risen since the early 1990s and more specialist education correspondents have been employed by (some) newspapers and broadcast media during this time, the professional practice of educational correspondents is a relatively 
under-examined area of study (e.g., Baker 1994). Not only the work of educational correspondents, but also the way education is covered in the news media more generally, have been a rather neglected topic for media and communication researchers (e.g., Baker 2000). The lack of literature on education in the media is underlined in the few research writings that do exist (e.g., MacMillan 2002). But there is an even more pressing gap in the literature when it comes to the topic of how science education is represented in the media. Even after extensive internet database and library searches and exchanges with various scholars working in different relevant fields, only very few studies about how mass media cover science education issues could be identified (e.g., Schwarzgruber 2006).

In contrast to the few scholarly works addressing science education in the media, the general topic of how the media covers science and technology issues has received a great deal of attention and the literature on the subject is, relatively speaking, extensive at least when compared to the topic of education new stories (e.g., Hansen 2009). Also the professional practices of correspondents who specialised in the coverage of science stories and the consequences for the production of science news has also received much attention (e.g., Allan 2009). Moreover, many correspondents and reporters specializing in science news have reflected in print on their professional practice themselves (e.g., Radford 1997). In this study the literature on the professional practice of science reporters and on science in the media more generally is used to supplement the findings and to address the lack of literature on (science) education in the media.

\section{Journalistic practice and the selection of sources}

Journalistic practices are not necessarily static between newsrooms, or across different desks (e.g., Holliman 2007). Furthermore, editors of different types of newspapers (e.g., popular, quality or weekly) have different priorities, which influence their news selection practices (e.g., McNair 1999). All hardcopy newspaper journalism is influenced by limited space and time-pressure under which articles often have to be written (e.g., Schudson 2003). Also the motivation to get stories ratified by various editors and sub-editors and into print is another factor in the production of newspapers that has an influence on the work of news reporters and specialist correspondents (e.g., Clayman and Reisner 1998). Here it is likely that various specialities of correspondents involved in reporting the news also affect the professional practice of journalists, their selection of sources and how they cover particular issues and debates (e.g., Peters and Heinrichs 2005).

Science journalists, for instance, visit scientific conferences, talks and presentations, read and follow scientific journals and receive 'embargoed' press releases from scientific institutions and pre-published articles from science journals (e.g., Holliman 2004). Journalists specialising in stories about education follow the news coverage on education on various media channels, keep in touch with teachers, head teachers and other professionals from the education world, and follow the moves of teaching unions, representatives of the government and education authorities (Hansen 2007). As such, both rely on highly selective sources and what information and sources will make it into the news is dependent on the personal professional judgement of the journalist as well as on their personal 'gut feeling' (e.g., Schultz 2007).

Specialist correspondents generally have established contacts (or a contact book) that they can rely on (e.g., Conrad 1999). Trust in sources develops through their ability of providing reliable and accurate information over time (e.g., Holliman 2000). In general, journalist-expert interactions can be characterized as symbiotic (e.g., Goodell 1987). This 
means not only the correspondent but also the source might benefit from media exposure. For example, media prominence might help scientific experts attract research funding more easily (e.g., Peters et al. 2008), or help them establish public expertise (e.g., Peters 2008). But since it takes time and energy to develop these special relationships, correspondents are constrained by this symbiotic dimension as well. If a source objects to the representation of their statements or the way they are presented in print, the source might cease to collaborate with the correspondent in future stories, thus depriving the journalist of a valuable social capital resource.

Erik Albaek (2011) distinguishes between different types of sources. For instance, 'ordinary citizens' (vox pops) can be used for identification of the readers with some statements. However, 'expert sources' provide 'compensatory legitimation', that is journalists can draw upon the authority of experts, but also serve as 'sparring partners' in developing interesting news stories with sufficient depth and breadth. At the same time more and more 'experiental' and 'experienced' experts, without certified expertise seem to appear in the media' (see Albaek 2011).

Expert sources are an essential factor in journalistic practice and the production of news, especially concerning news about science and technology (Albaek et al. 2003). Journalists and specialty correspondents can employ their sources for different uses. Peter Conrad (1999), for instance, asserts that different expert sources can be used to provide context, legitimization, explication, and balance in news accounts. Furthermore, Cynthia-Lou Coleman (1997) also stresses the importance of the use of some sources that can add credibility, legitimacy and authority to particular framings, especially in controversial issues that are concerning science and technology (for creationism cases see Taylor and Condit 1988). In general, scientists and researchers (especially those working at universities) are highly regarded in terms of trustworthiness and credibility (e.g., Sprecker 2002). But the selection of particular scientific expert sources that deviate from the consensus view of the scientific community can also be used to fuel controversy (e.g., Boyce 2006). Furthermore, the journalistic convention of balanced and fair reporting can also shape the source selection processes, as well as how sources are represented in print (e.g., Clarke 2008).

Journalists are generally able to choose which views they wish to represent directly (Dunwoody and Ryan 1987). Moreover, the order in which source quotes are presented can influence the way readers prioritize the facts of a story. However, journalists can also pick and choose which quotes best express their own point of view, thus functionally adding credibility to their particular bias (Tuchman 1972).

There are other professional and practical issues that need to be considered as well. Hans Peter Peters (2008), for instance, asserts that important factors influencing the likelihood of scientific experts appearing in the media are the relevance of a scientific source for a particular story, the visibility of the scientists (in publications, professional meetings and/or the media) but also their accessibility and media appropriateness. Furthermore, Conrad (1999) identified attributes that make some experts particularly 'good sources' for journalists. From a very practical point of view this means that not all expert sources are equally relevant for journalists (Nelkin 1995). According to Conrad, the fundamental criterion that constitutes a good source is their accessibility and also availability.

\footnotetext{
${ }^{1}$ Here it should be noted that in science and technology studies there is a lively debate about the nature of expertise and the distinction between experts and non-experts. Many scholars in this field see the boundaries between experts and laypeople becoming increasing blurred in practice (see Allgaier 2008).
} 
'Good sources' are not only knowledgeable and articulate, but more importantly they return reporters' phone calls (and/or emails) in time.

In addition, a 'good' expert source must give context to their statements as well as make them understandable to a lay public. Some sources are better at phrasing statements that work for particular newspapers than others. They can comment on a story in a succinct and straightforward manner, while conveying this often over a telephone conversation. These articulate experts can 'turn a phrase' and have the ability to deliver 'punchy' quotes. Space for (long) quotes is always limited and 'sound bites' make journalists' lives a lot easier.

Another factor that constitutes a 'good' expert source is often the prestige and 'sound' of the institution where the expert is employed. Reporters may also select 'predictable sources', experts whose views are well-known and who can often be expected to take certain positions and viewpoints (e.g., Conrad 1999). In sum, expert and other sources are selected not necessarily for their expertise alone. Correspondents also select along more practical lines like timeliness, articulation, institutional affiliation and even for an expert's world view.

Olga Linne (1993) points to the importance of personal relationships that journalists develop with their sources over time. These experiences can influence the perception reporters may hold about potential (expert) sources. A negative experience with a particular source or organization could mean a journalist relies on other sources the next time, and, in effect, that $\mathrm{s} /$ he censors some voices. Subjective selection can also be based upon what the journalist has pre-learned about a particular source through past media accounts of them (Kitzinger 2000).

In general though, it is often the first hand relationship between a source and a journalist which determines whose quote makes it into print. The literature on the professional practice of science correspondents also stresses that science reporting can be one-sided and that science journalists can over rely on prominent scientists, which might not be the most relevant sources for a particular story (e.g., Shepherd 1981).

\section{A public science education controversy: the case of Emmanuel College}

One public controversy that exemplifies unequal access to the media concerns the case of Emmanuel College in the UK. Here, it was claimed that the school was teaching creationism in science classes. This particular science education controversy received a significant amount of media attention in the UK. Various general and specialty journalists covered it, while relying upon a large range of different sources. The following is a brief synopsis of important events.

In January 2002, a newspaper specializing in education coverage reported that employees at Emmanuel College in North England rented rooms to Answers in Genesis, a fundamentalist creationist organization. The group planned a conference at the school for March of that year (Dean 2002). Timed with the conference, a series of articles were featured in The Guardian, a quality national newspaper, claiming that the school was not only teaching creationism in science classes but also undermining the theory of evolution (e.g., Branigan 2002). Until that time there were not a lot of reported problems with creationism being taught in schools in Britain. The national curriculum in England and Wales demands that evolution is taught in science classes (which are compulsory); creation myths of various cultural backgrounds can be taught in religious education (here students can opt-out). The reports in the The Guardian set off a media firestorm, revolving around the teaching of creationism/evolution in science classes. Hundreds of articles, letters and 
opinion pieces were subsequently published in the UK press during the following weeks and scientists, educators, politicians, members of various religious organizations, citizens and others got involved in the unfolding public debate.

It is important to note that Emmanuel College was not just any school. It consistently produced excellent exam scores among its pupils. The then 'Office for Standards in Education' (OFSTED) ${ }^{2}$ wrote a very favorable report about the school and the government designated it the status of beacon school. An issue that was central in the debate was that the school, as a City Technology College, was partly funded by the state and partly by the private sector. The sponsor of the school was Sir Peter Vardy's Vardy Foundation, a charitable trust that held long standing Christian ethos.

Jenny Tonge, a parliament member of the opposition party, took the opportunity to cite the Emmanuel College case in a session of parliament. She directly asked then Prime Minister Tony Blair to state his position on the issue. Blair backed the school for its good exam results, considered that the newspaper reports were exaggerated, and said that he welcomed diversity in education (Kallenbach 2002). The educators and the sponsor of Emmanuel College denied the accusations and stressed that all requirements of the national curriculum were followed in the school. This was later confirmed by education authorities, such as the Department for Education and Skills and OFSTED. Emmanuel College spokespeople, such as its head teacher Nigel McQuoid, emphasized the openness of the college to children of various religious denominations, including those with none. Further he stressed that children were offered both religious views on creation and the theory of evolution, so they could decide for themselves what they wanted to believe.

The issue of creationism being taught in science classes at Emmanuel College was also reported in scientific journals (Gross 2002) and other media outlets (e.g., TV and radio news). Having formed during the controversy, various action groups wrote petitions and called for public action concerning the issue (Allgaier 2010b). Opponents of the school consistently claimed that religious 'indoctrination' and 'brainwashing' was taking place and that the educators of the school, at the behest of their Christian sponsor, were 'peddling' creationism in the school and undermining the teaching of Darwin's theory of evolution (Allgaier and Holliman 2006).

\section{Dual methodological approach}

The results presented in this article are part of a more elaborate study on the public representation of science education (Allgaier 2008). Newspaper articles on the Emmanuel College controversy were sampled from eight national UK newspapers and their Sunday equivalents. Also included in this sample, were two regional/local newspapers (from the geographical area where the Emmanuel College is situated) and two UK newspapers

\footnotetext{
2 Today it is called 'Office for Standards in Education, Children's Services and Skills'. The office is the non-ministerial government department of Her Majesty's Chief Inspector of Schools in England (HMCI). HMCI and Her Majesty's Inspectors of Schools (HMI) are appointed by Order-in-Council and are thus office holders under the Crown. Though the inspectorate has existed since the mid-19th century, the office was reorganised under the Education (Schools) Act 1992, and is explicitly named in the Education and Inspections Act 2006. One of the tasks of OFSTED is to inspect and evaluate schools and to write and publish reports about it.
} 
specializing in education reporting. These sources were analyzed using qualitative and quantitative approaches to content analyses. ${ }^{3}$

The news reports were sampled starting January 1, 2002 and ending at February 20, 2004. The newspaper content was retrieved from the electronic newspaper archive LexisNexis. All the articles referred to the debate around the Emmanuel College during that time. They were coded for distribution over time and newspapers, names and bylines of the correspondents, types of articles, number of directly quoted sources, as well as the different issues of the controversy that were reported in the course of the debate. ${ }^{4}$ For this paper, the results of the quantitative content analysis are presented to determine the distribution of quoted sources in news report $(n=111)$ along with the journalistic specialty of their authors.

The quantitative results are then complemented with a qualitative approach to analyzing journalistic practice. In depth interviews were conducted with a subset of newspaper journalists that reported on the controversy. The difficulty of recruiting media professionals for interviewing purposes is underscored in the literature (e.g., Cook et al. 2006, p. 16). As a result, a range of different strategies were employed to recruit subjects for this study. More than 60 media professionals were initially contacted by postal mail. This was followed by email messages and telephone calls. In most cases, there was no reply. Eventually six journalists agreed to an interview. An additional correspondent specializing in education news was recruited through a collegial referral. ${ }^{5}$

The seven subjects included a correspondent specializing in science reporting employed by the UK national press, four correspondents that specialized in education reporting (three writing for the UK national press and one for a regional/local newspaper), a correspondent based in the United States who wrote primarily about education for both the US and UK press, and a freelance writer commissioned by one of the national newspapers for an article on the creationism controversy in Britain. The names of the interviewees have been withheld in the analysis section that follows. Quotes from the interviews are identified only by journalists' specialisation.

The interviews were conducted during October 13, 2005 to April 20, 2006. They took place face-to-face or over the phone. All interviews were conducted solely by the author. A semi-structured guide included open-ended questions that allowed the subject to direct the interview accordingly (Appendix). A digital recorder documented the interview, while the author handwrote notes during this process. The interviews were then transcribed and coded to identify different journalistic practices and source selection processes.

\footnotetext{
3 The names of the sampled newspapers are: Daily Telegraph; Sunday Telegraph; The Times; The Sunday Times; The Guardian; The Observer; The Independent; The Independent on Sunday; Daily Mail; Mail on Sunday; Daily Express; Sunday Express; The Sun; News of the World; Daily Mirror; Sunday Mirror; The Journal (Newcastle); The Northern Echo (Darlington); Times Educational Supplement (TES); Times Higher Education Supplement (THES).

4 Seven categories were employed to classify the sources (see Table 1). For a more detailed account of the methods used, categorisations and the sampling strategy, see Allgaier (2008).

5 The number of journalists and special correspondents interviewed in this investigation is limited and the structure of the sample is asymmetrical: most of the interviewed correspondents specialised in education. To supplement these findings the analysis of interviews with journalists and special correspondents is also grounded in the literature on media production and special attention is given to the literature on science in the media and the professional practice of science correspondents. This sample of seven media professionals is too small to provide a reliable account of the newspaper production side of the controversy. Nonetheless, these interviews do provide valid insights about the professional practices of these journalists. In addition, these data add to the knowledge about an under-researched population in the study of media accounts of science education.
} 
Qualitative analysis followed conventional guidelines suggested by Jensen (2002), Flick (2006) and Silverman (2006). Statements were grouped into different categories (e.g., source selection, assessment of source credibility, use of quotes etc.) in order to compare and contrast across all seven subjects. Individually, these statements were compared with text excerpts from the subject's published news reports on the controversy in order to identify consistency between oral and written accounts. Finally, the association between oral and written statements and sources used were framed within the published research on journalistic practices and reporting of science news. In the following, I present findings from this dual method approach.

\section{The selection of sources in the Emmanuel College case}

In this section I present findings from both the quantitative content analysis of 111 news reports and qualitative interviews with a sub-sample of reporters that covered the Emmanuel College debate. It should be noted that the sample upon which the quantitative analysis is based is limited. Figures are too small to provide a completely robust and statistical account. However, the following overview strongly suggests that different types of reporters relied on different combinations of sources in determining the significance and future consequences of this controversy.

\section{Description of the sample}

Table 1 describes the primary characteristics associated with the sample of 111 news reports that featured the Emmanuel College controversy. Almost half (55 articles) of the 111 news reports in the sample were written by specialized correspondents. The other half did not indicate any specialty of the authors. Education correspondents and education editors were the primary specialists that produced most of the news reports (33 articles).

The controversy was covered by a variety of specialist correspondents and general news reporters. This conforms to normal coverage patterns in science and technology reporting (e.g., Holliman 2004). However, on closer inspection the present analysis suggests that the distribution depends on the specific topics and issues which emerge as the controversy unfolds. For instance medical, environmental, or political affairs correspondents as well as general news reporters often cover general science and technology issues. In this controversy though, educational correspondents, science correspondents and general news reporters were the primary contributors. ${ }^{6}$

\section{Sources quoted by areas of specialty of correspondents}

Table 1 also demonstrates that a range of different expert sources was quoted in the sample. First, it is noteworthy that while educational and science correspondents quoted a range of sources, they each defer more to sources in their own respective fields of expertise. This is important to account for since the choice of sources often determines

\footnotetext{
${ }^{6}$ This was also the case because two newspapers specialised in education were included in the sample. Also, this story about science education fell within the specialist area of both of these types of correspondents.
} 


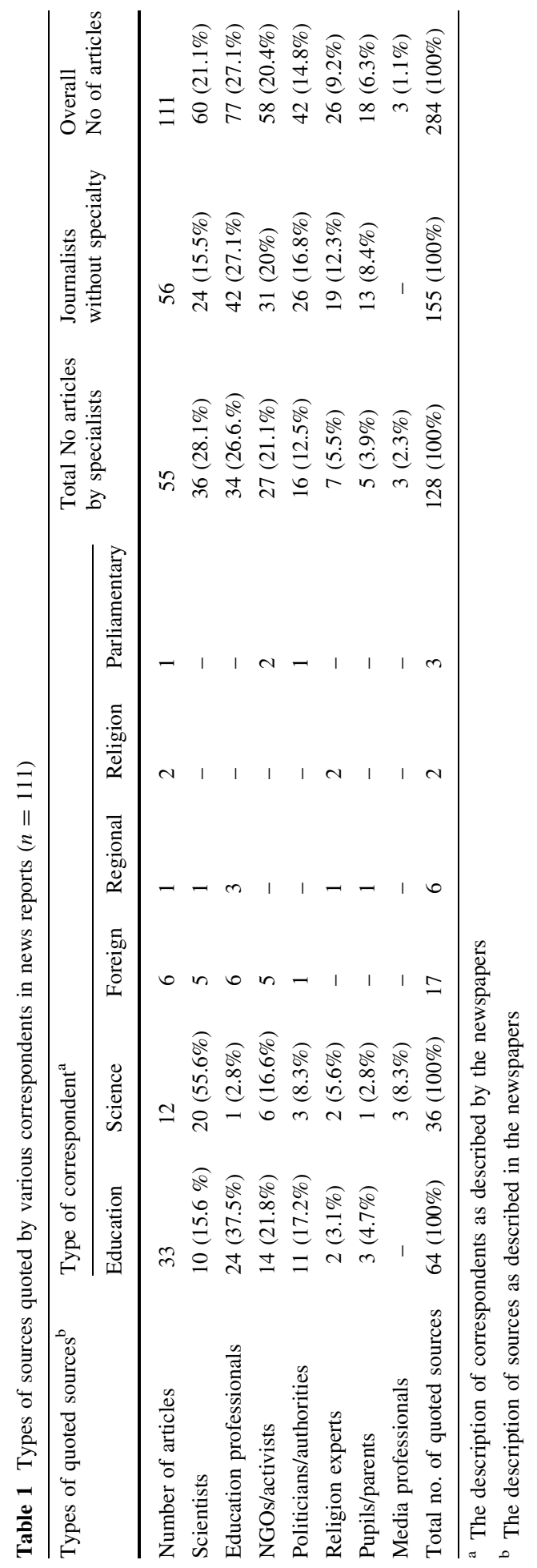


which of the various aspects of a controversy is emphasized. The reliance on scientists is especially striking in the case of the science correspondents where more than half $(55.6 \%)$ of the quoted experts are scientists. In contrast, education reporters (15.6\%) and generalists $(15.5 \%)$ relied substantially less on scientific experts. The reliance of science journalists on scientists as sources is well documented in the literature (e.g., Nelkin 1995), whereas the findings on the types of sources quoted by education correspondents add to the current literature in this under-researched area.

Second, both types of specialist correspondents relied very little on religious figures (education correspondents 3.1\%; science correspondents 5.6\%) and students and parents (education correspondents $4.7 \%$; science correspondents $2.8 \%$ ). By comparison, generalists depended more on religious figures $(12.3 \%)$ and students and parents $(8.4 \%)$.

Third, while there were differences in reliance on scientific, religious and citizen sources in the sample, the dependence on politicians and authorities was symmetrically distributed among educational correspondents $(17.2 \%)$ and generalist reporters $(16.8 \%)$. Education correspondents mostly relied on education professionals (37.5\%), but more than a quarter of all sources quoted by general reporters were also education professionals $(27.1 \%)$. In addition, the quoting of NGOs, campaigners, and activists is similarly distributed between educational correspondents $(21.8 \%)$ and generalists $(20 \%)$, and slightly less among the science correspondents $(16.6 \%)$.

\section{Journalistic practice of selecting sources}

The findings in Table 1 were supported by data from the qualitative interviews with seven reporters who covered the controversy.

Asked what characterized a typical education (expert) source the interviewed education correspondents presented a fairly consistent account. All underlined the importance of including those in the teaching profession in pedagogical controversies like these. Also mentioned was the relevance of those representing teaching unions like the National Union of Teachers or National Association of Head Teachers and individual head teachers. For three of the correspondents interviewed, these types of individuals were considered the most relevant sources on teaching and educational matters.

A second group of (expert) sources that were mentioned by all educational correspondents were those representing the government's point of view. Here the educational correspondents named sources such as spokespeople for the Department for Education and Skills or from OFSTED. However, the education correspondents agreed that the selection of sources depends on the actual story they are writing about. If the story is about the government and educational policy then the relevant sources are generally politicians and authorities, for instance representatives of the government or the political opposition or of the Department for Education and Skills. However, if a story is about a specific school, the education correspondents prefer accounts of sources that are as close to the school as possible, for instance:

Ideally, you speak to them [people involved in the story] and the nearer you can get to the people who are actually directly involved, the better, yes. So if it was a story about a particular school, you'd want to talk to the Head Teacher and the Governors at that school, if you can get through to them! If it's a Government story, if the Government's doing something, then you want to talk to the Government Department of Education (Educational Correspondent, 1 February 2006). 
Here, the head teacher of the school was generally mentioned as the first source they would like to talk to. Then they identified other teachers at the school (depending on the specific story), pupils at the school, also their parents and the representatives or spokespeople of the local teaching unions or the local education committee to gather local background 'gossip'. Another education correspondent, who covered the Emmanuel College controversy, assessed the credibility of interviewed sources by saying:

[...] The direct sources were the schools involved, the teachers, the local teacher union. I don't think the scientific community, so people like Richard Dawkins. Science teachers, national science teacher organisations. And the government and OFSTED as well, because it's been interesting to see how the Prime Minister has affected the schools, and how the OFSTED report for the schools has been very positive [...] generally we' $\mathrm{d}$ be going directly to the people involved or as directly as we can. [...] It depends on how close they are to it. A lot of the discussion about what has been happening in the Vardy schools has been very second hand. You get reports saying, they only teach in this way, which isn't fair or true. [...] how close they are to the story, so if they're talking about whether a school teaches something or not, and they're one of the teachers, that gives them a great advantage over someone outside the school, or a parent or somebody who wasn't actually there (Educational correspondent, 14 October 2005).

According to this reporter, the directness of the statement is very important, as is first-hand knowledge. What matter here is that the source is close to the events of the story, this gives them a special status and function as source-sort of a credible 'eyewitness' status of a person who was actually there. Hearsay and second-hand accounts are, in this regard, given low priority. In the case of the Emmanuel College controversy, scientists like Richard Dawkins (the most quoted expert in the sample, see Allgaier 2010a) were less important than the authentic accounts of sources that were directly involved.

The educational correspondents interviewed suggested that the head teacher of Emmanuel College, Nigel McQuoid, was one of the most important sources to talk to. Moreover, three of the education correspondents personally visited Emmanuel College or talked to Emmanuel College staff on the phone. Of these reporters, two noted that science teachers at the school were also especially relevant in framing this story.

The representatives of local teaching unions and local education committees were also mentioned by the education correspondents as providing historical, as well as other contextual, information relevant to the unfolding story. The head teachers and spokespeople of teaching unions were not only quoted for the directness of their accounts but also for their shared professional and specialized expertise in dealing with education in practice. Head teachers and educators with long teaching experience as well as spokespeople for teaching unions therefore have the utmost credibility for providing information for this aspect of the story. This suggests that they serve as expert sources for educational practices.

Other relevant sources mentioned were representatives of OFSTED for their positive assessment of Emmanuel College, Prime Minister Tony Blair since he personally supported the school, and representatives of the Department for Education and Skills for their expertise in assessing curriculum requirements. Two education correspondents also noted that Peter Vardy, and spokespeople of the Vardy Foundation, were relevant sources that needed to be interviewed or quoted in this specific story. Moreover, three of the educational correspondents stated that pupils and their parents also needed to be referred to.

Balanced reporting was important as well. For example, two educational correspondents represented views that strongly countered those held by Emmanuel College educators and 
the Vardy Foundation. These correspondents searched out spokespeople from humanist and secular organizations in the function of providing opposing views.

A look at the articles the interviewed education correspondents wrote in the sample confirms the explanations on source selection by education correspondents regarding Emmanuel College staff and Nigel McQuoid, official views and representatives of teaching unions. However, education experts from local education committees were not present in the sample (but it is still possible that education correspondents talked to them for background information and did not quote them in the articles). Also parents of pupils and/or pupils were quoted in only one case (and only in three cases in the 33 articles written by education correspondents-see Table 1).

Three of the education correspondents said that they have established contacts with sources from the education world. In practice, this means they often know where and how to get the voice of the profession and how to get official views on developments concerning education, for instance:

There's OFSTED, the teacher unions, the [unclear] Association, the Government, the various political parties, pressure groups... yeah. We're in touch with them all the time. [...] You know where to go to get the voice of the profession, the voice of the political parties. It's slightly more difficult if you want the voice of parents because there is a national confederation of parent teachers' associations, but you're more likely to go to a particular place, a particular area, and sort of choose people more or less at random really, because that's what you want is a general view. But yes, there's lots of places you can go to. You know those people to talk to, yes (Educational Correspondent, 1 February 2006).

Usually education correspondents call their contacts and have the relevant phone numbers in their contact books. However, the educational correspondents said that contacting and selecting relevant sources can be more difficult if the story is about a specific school. The correspondent first needs to find out who the relevant sources are and how to get in touch with them. Schools sometimes also deny access to journalists. Time pressure in producing stories and other practical restrictions can therefore influence which sources are contacted and also how long they are interviewed (e.g., Albaek 2011).

One noteworthy exception in approaching stories and also selecting sources was the view of an educational correspondent writing for a regional/local newspaper. This correspondent emphasized that the importance of regional/local newspapers is that they are part of local communities. This was described as an essential factor of difference in comparison with national newspapers. Being part of a local community also provided the opportunity — and in the view of this correspondent also the responsibility— to report diverse views from within that community which also had an effect on the selection of sources. This correspondent said that the representation of voices from the local community is partly the job of the local newspapers:

I think it shows how powerful the media can be when action groups get together and as soon as their cases are reported in the media they're picked up. And that generally tends to be when people are powerless so I think that just shows how important the role of the media is in terms of ensuring that ordinary people have a voice. Because it represents the little people often and they don't always get a chance to be heard. [...] I think the national newspapers tend to get interested when there's a big story there basically. And they do a good job in different ways; they're just different to local and regional papers. But I think it's important that local papers are there for people to use 
to get their voices across basically, whether that's writing a letter to their local paper or forming an action group and having their voices heard that way (Educational correspondent, 19 October 2005).

In this instance, the formation of an action group does not only have news value for this correspondent; it is also seen as part of the responsibility of regional/local newspapers to make the voices of ordinary citizens ('the little people') heard. This statement therefore refers to the democratic function of news media by representing the voice of the people. The action group may also have deliberately targeted the regional/local newspaper and made use of it through direct action and contacts to local journalists. However, this is also an interesting statement in terms of credibility, relevance and the selection of sources. This corroborates work that suggests the criteria for selection employed by local correspondents is slightly different from those employed by journalists writing for national newspapers (Hansen 2007).

This is confirmed when reviewing the articles. Ten of the eighteen parents and pupils, and three of the four spokespeople for a parent action group against Vardy-sponsored schools were quoted in the two regional/local newspapers in the sample. This is a comparatively large amount since the two regional/local newspapers (out of the 20 newspapers included in the sample) contain more than half of the quotes from parents and pupils. This can be seen as an indication that the criteria for source selection can also be influenced by the type of newspaper the correspondents are writing for. Regional/local newspapers consider local accounts seriously in order to gain and enhance their own relevance and credibility within the community they circulate in. This finding is very similar to the conclusions of Aldrige (2007) who asserts that all journalists have an 'imagined community' (Anderson 1983) in mind when they are producing media accounts. In essence, they feel responsible for representing the voices of the local community they are writing for.

Meanwhile, the science correspondent in the sample identified scientists and education policy makers as main sources. He stated that most of these sources were academics hostile to the idea of teaching creationism. A review of the articles this science correspondent authored about the Emmanuel College controversy confirms his reliance on these sources. Here it is likely that these different types of sources also have different functions, e.g., as scientific expert sources or experts in education policy.

The science correspondent keeps a contact list of established sources, that he considers being honest with him. Consider the following passage that describes how this particular correspondent assessed the credibility of sources in the Emmanuel College case:

[...] The usual sources: I phoned people who knew about it. [...] It would be scientists involved and education policy makers involved in this case. The school itself wasn't talking, I remember that. So you had to slightly skirt round it. But it would be academics that I would have spoken to, most of whom are hostile to the idea.

[...] I've got a list of contacts that I use regularly. [...] It depends on the source but if one of my sources is on my list of contacts these are people I trust. Often you get two different perspectives which is fine. You can write on the other hand so and so said such and such. They're on my contact list because I trust them and so far, so good (Science correspondent, 13 October 2005). 
This statement suggests first that personal acquaintance with the correspondents increases the likelihood of being represented. This is also confirmed in the literature (e.g., Tanner 2004). However, it is also probable that trustful relationships between sources and journalists can develop over time based on acquaintance. Geller et al. (2005) assume that trust facilitates the access that science journalists have to scientific sources, leads to higher quality interviews and therefore might also contribute to higher quality media reporting about science. Another point is made by the science correspondent Jim Detjen (1995, p. 62):

I cannot emphasize strongly enough the importance of developing a working relationship with reporters. If I have 15 phone messages on a busy day, I am far more likely to return first the calls from people I know.

This statement suggest that in order to find the advertence of a science journalist as a potential source it is a good idea to get to know them first. However, analytically it is necessary to distinguish between journalists' trust in sources and trust in source statements. Personal acquaintance does not need to have a direct influence on source's statements, but it might influence the trustfulness a journalist grants to a source as a person over time.

In his articles the science correspondent quoted scientific experts, secular action groups, a bishop who is defending the theory of evolution, and the MP Jenny Tonge who confronted Tony Blair in Parliament. Each of the quoted sources in the articles challenged the credibility of Emmanuel College. These reports are not balanced according to conventional journalistic norms. And the sources he relied upon were not as close to Emmanuel College as those used by the education correspondents. The science correspondent's approach therefore appears less proactive than that of the education correspondents, who directly searched out their contacts at the school. The science correspondent only indirectly referenced the school, when he quoted from the Emmanuel College prospectus (available online), suggesting that creationism is taught in science classes. To justify this indirect approach, he stated, 'the school itself wasn't talking'. This account is in stark contrast to the experience of three education correspondents all of whom commented that representatives and the staff at Emmanuel College were very open towards journalists and also employed PR experts to get their view across. They reported that access to the school was granted to all education correspondents that wanted to visit it. Given these contradictory statements, this does suggest that the school may have been selective about which journalists it chose to speak to (or that the science correspondent did not really make a great effort to get to speak or visit the school). Although the science correspondent refers to the journalistic convention of balancing accounts in his interview, the trust he places on established contacts seems to outweigh this norm in this case. In his articles on the Emmanuel College case, a range of different sources (scientists, a bishop, a politician and humanist activists) was quoted, but only one quote was from the Emmanuel College prospectus. When prompted to explain this, the science correspondent said:

I approached it [the story] completely cynically and against creationism. I'm the science editor so what do you expect? So I wasn't going to go in there particularly with a very fair and open mind but I can't remember the story I wrote. But I was writing from a very one-sided perspective in this case, not something that should be encouraged and should be as fair as possible. But sometimes bugger it. Life's too short and if people are being stupid you've got to say (Science correspondent, 13 October 2005). 
In the science correspondent's view, sources advocating creationism to be included in science education deserved no representation. And if they are included in stories, they should be countered by overwhelming evidence from the scientific consensus viewpoint. Subsequently, the way the science correspondent reported this issue effectively reinforced the consensus view of the scientific community (see also Dearing 1995).

It is noted in the literature that science correspondents occasionally show signs of deference towards science and scientists, limiting their ability to produce objective and balanced accounts (e.g., Goodell 1989). Science correspondents usually agree with the concept of modern science as superior method for producing reliable knowledge about the physical world. However, they also might not want to be too critical about what is happening in the scientific world since they are still dependent on scientists as their most important sources (Hansen 1994). This is a negative consequence of the symbiosis between specialist correspondents and their sources.

In contrast, educational correspondents stressed the importance of balanced reporting in the Emmanuel College controversy. Consider the following passage by one educational correspondent assessing the impact that mistrust in authorities could have in the Emmanuel College case:

I'm sure [concerned parents] felt that they had perhaps turned their backs for five minutes and their children were being taught that God created the world. But whether $\mathrm{He}$ [God] did or not is not really for me to comment because my job was just to present the story really in as balanced a way as I could (Educational correspondent,

19 October 2005).

The trustworthiness and reliability of, as well as personal acquaintance and experiences with sources, were determining factors that guided educational correspondents in their reporting. However, the sources had to be knowledgeable about the particular subject and have a general command of their field. Another, if not lesser factor, may also be the view the sources hold, or are perceived to hold, about a particular issue. Nevertheless, sources that have personal relationships with journalists covering their field of expertise seem to enjoy a strategic advantage in receiving a credible presentation when compared to unknown or unfamiliar sources. This combination of social and cultural capital (Bourdieu 1986) works well for those who gain regular access to media professionals. Those who don't-for instance 'the little people' - have to rely on other access points, e.g., the democratic function of 'the fourth estate'.

The process of searching out sources worked out very differently for the freelance writer. The freelancer received an assignment for a feature on creationism in British faith schools from the education editor of a national Sunday newspaper. The freelancer admitted he was less well-connected in the area of education and did not have a pool of sources that could be relied on in this particular story. However, this journalist mentioned that he enjoyed informal networks with other freelance writers. This was vital, since although the editors of the newspaper briefed the freelance writer, they did not offer him a list of sources he must or should interview. After the briefing, which was based on the reading of a 'sheaf of press cuttings' he got from the newspaper and the use of internet search engines the freelancer had to sit down and think about which sources were particularly relevant, easily accessible and possible to get hold of in a very short space of time. Tools that assisted the freelancer in doing so were internet search engines, the phonebook and the telephone. The freelancer summarized this process the following way: 
As you can see, the choosing of sources is hardly a science but has more to do with logic, lateral thinking, experience - that is, knowing how to obtain informationcoincidence and a degree of practicality and pragmatism about how, where and when you conduct interviews. It's an imperfect world-and you must move fast (Freelancer, 20 April 2006).

This statement suggests, again, that time constraints influence the consultation of sources. In turn, the potential pool of contacts available to any given correspondent grows with each assignment. The investigation and newsgathering strategies develop with the experience one has on the job. This particular freelancer had written six education related stories before this assignment. His experience so far suggested to him that it was 'pretty much de rigueur' for education stories to quote a source that represents (1) the voice of the profession (he mentions teaching unions such as the National Union of Teachers) and (2) the voice of authorities (in this case the Department for Education and Skills). This is consistent with the literature on education correspondents and the selection of sources (Hansen 2007). The freelancer asserted that these two types of institutional sources rarely agree on a particular topic in education. Thus, given time constraints and little preknowledge of the conceptual geography, this binary strategy is 'perfect' for the freelance journalist. This statement also emphasizes the underlying journalistic convention of balancing accounts that, in this case, can also be used to foster the news value of disagreement, conflict and controversy (e.g., Miller 1999).

In contrast to the specialist correspondents who often have some past experience, and perhaps even personal relationships with their contacts, non-specialist correspondents have to evaluate the credibility of sources case by case.

While the freelancer was free to decide what sources to contact, practical considerations of time and availability influenced his source selection processes. The way he assessed the relevance of sources was similar to strategies employed by educational correspondents, who often rely on their own professional expertise, while guided by previous media accounts. In this way, the freelancer could build upon the experiences of correspondents who had come before him (e.g., Luhmann 2000).

\section{Journalistic speciality has an influence on representations of science education in the media}

Primary and secondary science education is a key activity that can influence a life-time of attitudes towards science and technology. However, little is known about how science education issues are represented in the media. The present article addressed this gap in the literature by examining the journalistic practice of selecting sources in covering a science education controversy. The dual method employed identified key similarities and differences of how several types of specialist and non-specialist correspondents selected and quoted their sources. The two kinds of specialists most prominently reporting on the Emmanuel College creationism controversy were educational and science correspondents. An analysis of quantitative data based on 111 news reports suggests that the specialty of journalists affected the selection of sources. The range of sources quoted by educational correspondents was broader than the range of sources quoted by their science counterparts. Moreover, science correspondents relied heavily on scientists as sources, corroborating previous literature (e.g., Shepherd 1981). 
These findings were supported by qualitative interviews with a subset of journalists who covered the controversy. Educational correspondents consistently conveyed their preference for sources close to the issue. This included those that represented the teaching profession, government institutions, teachers and school administrators as well as pupils and parents (Hansen 2007). However, closeness to particular story serves as one particular role of a source as sort of an 'eyewitness' account. Nonetheless, education professionals and representatives of authorities or teaching unions could also be represented in the role as expert sources for their knowledge and experience about dealing with particular educational policies.

The science correspondent emphasized trust with established contacts. The specialist knowledge, status and reputation among peers that these sources enjoy were key criteria for their selection. This suggests that they were mainly selected in the role as expert sources regardless of their experiential proximity to the controversy.

The geographical dimension also influenced the selection process. An educational correspondent writing for a regional/local newspaper reported a feeling of obligation to represent local community voices, within which the newspaper he wrote for circulated. Here we find different hierarchies of credibility (Becker 1967), authenticity and directness, based on the roles of the sources as expert sources, direct sources or members of local communities. How these play out in hectic and short production periods can affect the overall framing of sources and source statements, as well as the issues that are addressed in the resulting articles (Allgaier 2008).

Another factor that influenced the selection of sources was the journalistic norm of objective reporting. The idea that 'objective' news reporting is possible has been challenged consistently in the academic literature (e.g., Allan 2000). However, the norm of objective reporting still serves as a professional ideal that is employed by journalists for various reasons, but can take on different forms in the practice of journalism. It involves criteria such as factual, neutral and balanced reporting which is often related to a general 'fairness' of accounts, accuracy, and impartiality to ensure that bias or sensationalism is avoided (e.g., McQuail 2003). In practice, objectivity in journalism is not a static concept. Different reporters and newspapers can produce different accounts but still claim to be objective (e.g., Ryfe 2006). The notions of objectivity among journalists and scientists are also quite different ones (e.g., Peters 1995). Whereas in science the consensus in the scientific community about an issue being verified by empirical evidence is crucial in determining the validity of an account the journalistic norm of balance leads to a view about objectivity that emphasizes disagreement through the presentation of two or more (often polarized) views on one issue. Often journalists assume that different views on an issue will balance each other out and therefore help to get a 'full picture' so that the readers can make their minds up. The journalistic norm of balanced reporting can have consequences not only for controversies amongst scientists but also when there is consensus amongst the scientific community (e.g., that the theory of evolution is a scientific theory and creationist explanations are not scientific ones) and scientific knowledge is attacked from outside the scientific community. However, there were different notions of legitimacy held by correspondents with regard to the Emmanuel College case that informed them about what was objective or not. Put another way, correspondents with different professional and personal ideals assess the representation of sources and the coverage of the debate in different ways (Allgaier 2008). Whether articles needed to be balanced or not influenced which types of sources were represented. In this case, education correspondents and the freelancer accepted the creationism/evolution debate as legitimate and were compelled to report it in a balanced way. As a result their articles represent a wide range of voices. 
In contrast, the science correspondent did not recognize the legitimacy of the controversy; therefore, from his point of view, accounts did not need to be balanced. His professional deference to the scientific explanation eclipsed statements from people supporting a creationist agenda. That science correspondents tend not to balance accounts about creationism, while other specialists and general journalists do, has been reported in the literature before (e.g., Rosenhouse and Branch 2006). This suggests that news accounts produced by specialist science correspondents could effectively extend the boundary work of science, which often leads to particular framings of reality (Gieryn 1983). In this case, accounts produced by science correspondents are more likely to prioritize the scientific consensus in issues pertaining to controversies over science and science education (e.g., about how science should be taught in school) over competing accounts. Representations constructed by other types of media professionals, meanwhile, might produce accounts of science education relying on a broad range of sources and stakeholders like science education scholars, practitioners, administrators, pupils and parents (e.g., a citizenship perspective) instead of just practicing scientists. This could lead to entirely different framings of stories about science education (Allgaier 2008). Science journalists effectively contribute to the boundary work of science and representations of science education in the media could be used to effectively extend the boundary work of scientific experts and their notions about the nature of science. However representations of science education also have the potential to question conventional views and highlight alternative views on science education (for instance by asking pupils and students why they enjoy science or why they are put off by scientific subjects; or by interviewing science teachers about the challenges of teaching science to young people). ${ }^{7}$

These qualitative findings correspond to the quantitative analysis, which considered what types of sources were quoted by what type of correspondent. Here, the combination of data on media content and media production was particularly fruitful since it allowed a cross-validation of results from the two different types of analyses. In this instance, the science correspondent and the educational correspondents had different criteria for the selection of sources and also varying notions of objectivity based on balancing source accounts. These are the results of slightly different journalistic norms practiced by distinct specialties when it comes to the selection of sources. From this view it is not exclusively an issue of cultural hegemony concerning whose quotes make it into the press. Instead the data suggest that the specific 'desk' that covers a particular type of story can have a unique influence on which sources are selected, how they are represented, and also which issues will be addressed in newspaper accounts. This is especially relevant in stories about science education that can be covered as readily by science correspondents, educational correspondents, and general journalists. However, potential sources will have a greater likelihood of being represented if they take professional journalistic practices into account. For instance, when they can be reached easily and quickly, and when they are available and willing to comment on a particular story. Both educational and science correspondents establish working relationships with sources they contact regularly and it is likely that

\footnotetext{
${ }^{7}$ For instance, in the UK press it seemed to be the case that the introduction of science for citizenship components in science education in secondary schools were sometimes commented by established scientific experts as "fit for the pub" or "dumbing down of science education" etc. In cases where science teachers were interviewed they could explain what the actual purpose of these courses are and that they are helpful in engaging many children with science subjects. Students that already took these courses explained in interviews that these courses made science more interesting to them and that they finally understood the relevance of science for their own lives. As a result they said that they were more motivated to learn about science (see also Moran 2007).
} 
reliable sources in the past will receive preferential treatment before potentially relevant sources that are unknown.

The analysis presented in this paper has provided some insights into the professional practice of specialist correspondents reporting a single story about science education. These snapshots addressed some important areas of professional journalistic practice. However, the empirical data presented in this paper is limited and it would require more interviews with specialised correspondents and general news reporters to gain a fuller picture of the similarities and differences in journalistic practices. The data presented are furthermore exclusively based on one single case that was reported in the UK press. Here it would helpful to compare the data provided to further analyses of representations of science education in the media, also in other countries and media channels, in order to see whether the results could be generalized or not. Another interesting question that arises from this study is who it is that assigns particular 'desks' to cover a certain story and how the selection processes of various specialist and general news correspondents take place in the news production process (see Lublinski 2004). Here it would be interesting to see whether there are consistent patterns of statements about source selection and journalistic practice among specialist correspondents, such as science correspondents and educational correspondents, and how they differ from each other and those of general news reporter in the production of stories about science education.

Nonetheless, primary and secondary science education, as activities with lasting influence, hold the potential to contribute to better scientific citizenship and fruitful relations between science and society in the long term (e.g., Jenkins 1999). For this reason, it is important for scholars to continue to systematically investigate how the 'purposes' of science education are communicated to the public and decision-makers. Also important to account for is who is reporting the news, as well as how different pundits that publicly speak out on behalf of the education of children (and grownups), are selected and represented by various media professionals.

Acknowledgments I would like to thank Professor Rick Duque, Professor Hans Peter Peters and Dr. Daniel Nehring for their comments and helpful suggestions on previous versions of this article; my Ph.D. supervisors Dr. Rick Holliman and Professor Eileen Scanlon for their help and advice before, during and after conducting the research; the reviewers and editors of CSSE for their helpful and constructive comments and suggestions; and especially the journalists interviewed for participating in this study. This article is based on research conducted for the author's Ph.D. at the Open University, UK, where he was funded by a Research Grant from the Open University.

Open Access This article is distributed under the terms of the Creative Commons Attribution Noncommercial License which permits any noncommercial use, distribution, and reproduction in any medium, provided the original author(s) and source are credited.

\section{Appendix: Core set of questions that the interviewed media professionals were asked in the interviews}

- Which are your professional fields of interest/expertise (and why)?

- How many years have you been working as a journalist/specialist correspondent?

- Concerning the debate around Emmanuel College, what were the key issues?

- According to your experience what was it that made this issue newsworthy?

- Why have you reported this issue? 
- Where did you get your information from about this issue and how did you approach this story?

- Which sources are in your opinion of particular importance in this story?

- How do you get in touch with your sources?

- How do you assess information provided by your sources?

- How do you select which quotes get in the reports?

\section{References}

Albaek, E. (2011). The interaction between experts and journalists in news journalism. Journalism, 12(3).

Albaek, E., Christiansen, P. M., \& Togeby, L. (2003). Experts in the mass media: Researchers as sources in Danish daily newspapers, 1961-2001. Journalism and Mass Communication Quarterly, 80, 937-948. Aldrige, M. (2007). Understanding the local media. Maidenhead: Open University Press.

Allan, S. (2000). News culture (2nd ed.). Buckingham: Open University Press [first published 1999].

Allan, S. (2009). Making science newsworthy: Exploring the conventions of science journalism. In R. M. Holliman, J. Thomas, S. Smidt, E. Scanlon, \& E. Whitelegg (Eds.), Practising science communication in the information age: Theorizing professional practices (pp. 149-165). Oxford: Oxford University Press.

Allgaier, J. (2008, February 26). Representing science education in UK newspapers: A case study on the controversy surrounding teaching the theory of evolution and creationism in science classes. $\mathrm{PhD}$ Thesis. The Open University. Retrieved December 20, 2009, from http://kn.open.ac.uk/public/ document.cfm?docid=11066.

Allgaier, J. (2010a). Scientific experts and the controversy about teaching creation/evolution in the UK press. Science \& Education, 19, 797-819.

Allgaier, J. (2010b, November 23). Discursive coalitions and collaborative networks of experts in a public creationism controversy in the UK. Public Understanding of Science. Retrieved January 31, 2011, from http://pus.sagepub.com/content/early/2010/11/16/0963662510383385.full.pdf + html.

Allgaier, J., \& Holliman, R. M. (2006). The emergence of the controversy around the theory of evolution and creationism in UK newspaper reports. The Curriculum Journal, 17, 263-279.

Anderson, B. (1983). Imagined communities: Reflections on the origins and spread of nationalism. London: Verso.

Baker, M. (1994). Media coverage of education. British Journal of Educational Studies, 42, 286-297.

Baker, M. (2000). Does education get the media it deserves? Inaugural Lecture. London: Institute of Education.

Becker, H. S. (1967). Whose side are we on? Social Problems, 14, 239-247.

Bourdieu, P. (1986). The forms of capital. In J. G. Richardson (Ed.), Handbook of theory and research for the sociology of education (pp. 242-258). Westport: Greenwood.

Boyce, T. (2006). Journalism and expertise. Journalism Studies, 7, 889-906.

Branigan, T. (2002). Top school's creationists preach value of Biblical story over evolution: State-funded secondary teachers do not accept findings of Darwin. The Guardian, March 9, 2002, 3.

Clarke, C. E. (2008). A question of balance: The autism-vaccine controversy in the British and American elite press. Science Communication, 30, 77-107.

Clayman, S. E., \& Reisner, A. (1998). Gatekeeping in action: Editorial conferences and assessments of newsworthiness. American Sociological Review, 63, 178-199.

Coleman, C. L. (1997). Science, technology and risk coverage of a community conflict. In D. Berkowitz (Ed.), Social meaning of news (pp. 483-496). Thousand Oaks: Sage.

Conrad, P. (1999). Use of expertise: Sources, quotes, and voices in the reporting of genetics in the news. Public Understanding of Science, 8, 285-302.

Cook, G., Robbins, P. T., \& Pieri, E. (2006). 'Words of Mass Destruction': British newspaper coverage of the genetically modified food debate, expert and non-expert reactions. Public Understanding of Science, 15, 5-29.

Dean, C. (2002). CTC to host creationists. Times Educational Supplement, January 25, 2002, 2.

Dearing, J. W. (1995). Newspaper coverage of maverick science: creating controversy through balancing. Public Understanding of Science, 4, 341-361.

Detjen, J. (1995). The media's role in science education. Bioscience. Supplement: Science and Biodiversity Policy, 45, 58-63. 
Dunwoody, S., \& Ryan, M. (1987). The credible scientific source. Journalism Quarterly, 61, 21-27.

Flick, U. (2006). An introduction to qualitative social research. London: Sage.

Geller, G., Bernhardt, B. A., Gardner, M., Rodgers, J., \& Holtzmann, N. A. (2005). Scientists' and science writers' experiences reporting genetic discoveries: toward an ethic of trust in science journalism. Genetics in Medicine, 7, 198-205.

Gieryn, T. F. (1983). Boundary-work and the demarcation of science from non-science: Strains and interests in professional ideologies of scientists. American Sociological Review, 48, 781-795.

Goodell, R. (1987). The role of mass media in scientific controversy. In H. T. Engelhardt \& A. L. Caplan (Eds.), Scientific controversies. Case studies in the resolution and closure of disputes in science and technology (pp. 585-597). Cambridge: Cambridge University Press.

Goodell, R. (1989). Problems with the press: Who' s responsible? In D. E. Chubin \& E. W. Chu (Eds.), Science off the pedestal. Social perspectives on science and technology (pp. 31-40). Belmont: Wadsworth.

Gross, M. (2002). US-style creationism spreads to Europe. Current Biology, 12, 265-266.

Hansen, A. (1994). Journalistic practices and science reporting in the British press. Public Understanding of Science, 3, 111-134.

Hansen, A. (2007). Producing education coverage - a study of education correspondents and editors in the national and regional press. In L. Haragreaves, M. Cunningham, A. Hansen, D. McIntyre, C. Oliver, \& T. Pell (Eds.), The status of teachers and the teaching profession in England (pp. 67-83). London: Department for Education and Skills.

Hansen, A. (2009). Science, communication and media. In R. M. Holliman, J. Thomas, S. Smidt, E. Scanlon, \& E. Whitelegg (Eds.), Practising science communication in the information age: Theorizing professional practices (pp. 105-127). Oxford: Oxford University Press.

Holliman, R. (2000). Representing science in the UK news media: 'Life on mars?', Cell nucleus replacement and gulf war syndrome. Unpublished Ph.D. Thesis. Milton Keynes: The Open University.

Holliman, R. (2004). Media coverage of cloning: A study of media content, production and reception. Public Understanding of Science, 13, 107-130.

Holliman, R. (2007). Reporting environmental news: the evolving context for newspapers in the digital age. Frontiers in Ecology and the Environment (Pathways to Effective Communication Series), 5, 277-278.

Jenkins, E. W. (1999). School science, citizenship and the public understanding of science. International Journal of Science Education, 21, 703-710.

Jensen, K. B. (2002). The qualitative research process. In K. B. Jensen (Ed.), A handbook of media and communication research: Qualitative and quantitative methodologies (pp. 235-253). London: Sage.

Kallenbach, M. (2002). School creationism is exaggerated, says PM. The Daily Telegraph, March 14, 2002, 12.

Kitzinger, J. (2000). Media templates: Patterns of association and the (re)construction of meaning over time. Media, Culture \& Society, 22, 64-84.

Linne, O. (1993). Professional practice and organization: environmental broadcasters and their sources. In A. Hansen (Ed.), The mass media and environmental issues (pp. 69-80). Leicester: Leicester University Press.

Lublinski, J. (2004). Wissenschaftsjournalismus im Hoerfunk. Redaktionsorganisation und Thematisierungsprozesse. Konstanz: UVK.

Luhmann, N. (2000). The reality of mass media. Cambridge: Polity.

MacMillan, K. (2002). Narratives of social disruption: education news in the British tabloid press. Discourse: Studies in the Cultural Politics of Education, 23, 27-38.

McCune, C. A. (2003). Framing reality: Shaping the news coverage of the 1996 Tennessee debate on teaching evolution. Journal of Media and Religion, 2, 5-28.

McNair, B. (1999). News and journalism in the UK. London: Routledge.

McQuail, D. (2003). Mc Quail's mass communication theory. London: Sage.

Miller, D. (1999). Mediating science. Promotional strategies, media coverage, public belief and decision making. In E. Scanlon, E. Whitelegg, \& S. Yates (Eds.), Communicating science: Contexts and channels (pp. 206-226). London: Routledge.

Moran, S. (2007). What is science education for? School Science Review, 89, 97-102.

Nelkin, D. (1995). Selling science. How the press covers science and technology. New York: W.H. Freeman and Company.

Peters, H. P. (1995). The interaction of journalists and scientific experts: Co-operation and conflict between two professional cultures. Media, Culture \& Society, 17(4), 31-48.

Peters, H. P. (2008). Scientists as public experts. In M. Bucchi \& B. Trench (Eds.), Handbook of public communication of science and technology (pp. 131-146). London and New York: Routledge. 
Peters, H. P., \& Heinrichs, H. (2005). Öffentliche Kommunikation über Klimawandel und Sturmflutrisiken. Bedeutungskonstruktion durch Experten, Journalisten und Buerger. Juelich: Forschungszentrum Juelich.

Peters, H. P., Heinrichs, H., Jung, A., Kallfass, M., \& Petersen, I. (2008). Medialization of science as a prerequisite of its legitimation and political relevance. In C. Donghong, M. Claessens, T. Gascoigne, J. Metcalfe, B. Schiele, \& S. Shi (Eds.), Communicating science in social contexts (pp. 71-92). Beijing: Springer.

Radford, T. (1997). Science for people who don't want to know about science. Accountability in Research, $5,39-43$.

Rosenhouse, J., \& Branch, G. (2006). Media coverage of 'Intelligent Design'. BioScience, 56(3), $247-252$.

Ryfe, D. M. (2006). The nature of news rules. Political Communication, 23, 203-214.

Schudson, M. (2003). The sociology of news. New York: W.W. Norton.

Schultz, I. (2007). The journalistic gut feeling: journalistic doxa, news habitus and orthodox news values. Journalism Practice, 1, 190-207.

Schwarzgruber, M. (2006). Die PISA-Studie und ihre mediale Darstellung. Unpublished Master Thesis. University of Salzburg, Austria.

Shepherd, R. G. (1981). Selectivity of sources: reporting the marijuana controversy. Journal of Communication, 31, 129-137.

Silverman, D. (2006). Interpreting qualitative data. London: Sage.

Sprecker, K. (2002). How involvement, citation style, and funding source affect the credibility of university scientists. Science Communication, 24, 72-97.

Tanner, A. H. (2004). Agenda building, source selection, and health news at local television stations: A nationwide survey of local television health reporters. Science Communication, 25, 350-363.

Taylor, C. A., \& Condit, C. M. (1988). Objectivity and elites: A creation science trial. Critical Studies in Mass Communication, 5(4), 293-312.

Tuchman, G. (1972). Objectivity as strategic ritual: An examination of newsmen's notions of objectivity. The American Journal of Sociology, 77, 660-679.

Turnstall, J. (1971). Journalists at work. Specialist correspondents: their news organizations, news sources, and competitor-colleagues. London: Constable.

\section{Author Biography}

Joachim Allgaier is a postdoctoral researcher in the project 'Normative expectations in media coverage of research as a form of informal science governance'. He is based at the Juelich Research Center in Germany and teaching at RWTH University Aachen, Germany. Before that he was employed as a postdoc at the Department of Social Studies of Science at the University of Vienna in Austria. He studied sociology, psychology and intercultural communication at Munich University, Germany, and was a visiting student in the Science, Technology and Society Program at Maastricht University, the Netherlands. He conducted research on the public representation of scientific and technological experts and the public representation of science education at the Open University, UK, where he was also employed as a research assistant. He holds a Master's Degree in Sociology from Munich University (LMU) and a PhD in Sociology from the Open University, UK. 